\section{SM Journal of Hepatitis Research and Treatment}

\section{Article Information}

Received date: Aug 05, 2015

Accepted date: Jul 11, 2015

Published date: Jul 20, 2015

\section{${ }^{*}$ Corresponding author}

Furqaan Ahmed, South city Hospital,

Pakistan, Email: furqaan@hotmail.com

Distributed under Creative Commons CC-BY 4.0

Keywords Boceprevir; Hepatitis C; Telaprevir; Pakistan

Article DOI 10.36876/smjhrt.1003

\section{Barriers to Directly Acting Antiviral Agent Use for Chronic Hepatitis $\mathrm{C}$ in South and South East Asia}

\author{
Furqaan Ahmed ${ }^{1 \star}$ and Khawar Mehdi ${ }^{2}$ \\ ${ }^{1}$ South City Hospital, Pakistan \\ ${ }^{2}$ Getz Pharma, Pakistan
}

\section{Abstract}

Introduction: The treatment of chronic hepatitis $\mathrm{C}$ has been dramatically altered by the development of Directly Acting Antiviral (DAA) agents. The first two of these agents, telaprevir and boceprevir have resulted in significantly improved Sustained Virologic Response (SVR) rates in previously difficult to treat genotype 1 patients in the West. There appears to be very limited use of these new DAA agents in South and South East Asia.

Objective: To assess obstacles to DAA use among hepatologists in South and South East Asia.

Methods: Hepatologists from South and South East Asia attending the International Gastroenterology and Hepatology Forum (IGHF) in Yangon, Myanmar in November 2012 were surveyed, using a questionnaire, regarding DAA usage.

Results: 67 hepatologists were included in this study. The doctors were from the following countries: Pakistan 24 (36\%), Sri Lanka $2(3 \%)$, Myanmar 25 (37\%), Philippines 8 (12\%), Laos $5(7 \%)$, and Cambodia 3 $(4 \%)$. Eleven doctors said DAAs were available in their country (3 from Philippines, 4 from Burma, and 7 from Pakistan) and 4 doctors from Pakistan had previously prescribed DAAs. When asked about obstacles to DAA use in their countries, the following reasons were cited: 1 . High cost $54 \%$ (36), 2. Lack of availability $54 \%(36)$, and 3 . Lack of relevance of these DAAs to the genotypes prevalent in their countries $12 \%(8)$.

Conclusion: Based on this sample of hepatologists representing six countries from the region, there appears to be limited DAA use in South and South East Asia. Issues relating to cost, availability, and efficacy in prevalent genotypes limited DAA use in this region. These issues need to be addressed both for the existing DAAs as well as for the array of newer agents in development.

\section{Introduction}

The treatment of chronic hepatitis $\mathrm{C}$ has been revolutionized by the development of Directly Acting Antiviral (DAA) agents. The first two of these agents, the first generation protease inhibitors telaprevir and boceprevir, are available in the West and have resulted in significantly improved Sustained Virologic Response (SVR) rates in previously difficult to treat genotype 1 patients (with pegylated interferon) [1-4]. The first generation protease inhibitors, telaprevir and boceprevir, have well established efficacy in HCV genotype 1 patients [1-4]. These medicines have limited efficacy against genotypes other than genotype 1 [5]. The genotype-specific efficacy of these medicines can account, in part, for the lack of their use in some of the countries in the region. In Pakistan, the prevalent genotype is genotype 3 [6]. Sri Lanka also has genotype 3 predominance [7]. Genotype 6 is the predominant in South East Asia [8]. For example, in Myanmar genotype 6 is the predominant genotype [9].

The pivotal clinical trials for these medicines have been conducted in the United States and Western Europe. There is no published data on the use of these agents in South and South East Asia. The objective of this study is to assess DAA usage among hepatologists in South and South East Asia.

\section{Methods}

This study was conducted by surveying hepatologists from South and South East Asia attending the International Gastroenterology and Hepatology Forum (IGHF) in Yangon, Myanmar in November 2012. The IGHF is a forum created to bring together Gastroenterology and Hepatology faculty, practitioners, and trainees from different countries in the region on a single platform to exchange ideas, learn from one another, and build ties in order to improve the state of gastrointestinal and liver healthcare and research in their respective countries. Using a questionnaire, demographic and practice date were collected including age, gender, type of practice setting and number of years in practice. Gastroenterology trainees were excluded. Questions were asked about DAA use in their countries and personal DAA use. Finally, the hepatologists were questioned regarding perceived barriers to the use of DAAs in their respective countries. The study was approved by the Institutional

\title{
ISSN: 2573-3672
}


Review Board at South City Hospital, Karachi, Pakistan. Data was entered and analyzed using SPSS version 197.

\section{Results}

67 hepatologists were included in this study. 70\% (47) were male and 30\% (20) were female. The average age of participants was 48 . $67 \%$ (45) were in academic practice. The doctors had been in practice for a time period ranging from one to 33 years. The doctors were from the following countries: Pakistan 24 (36\%), Sri Lanka 2 (3\%), Myanmar 25 (37\%), Philippines 8 (12\%), Laos 5 (7\%), and Cambodia 3 (4\%). All treated hepatitis C infected patients. Eleven doctors said DAAs are available in their country (3 from Philippines, 4 from Burma, and 7 from Pakistan) and four doctors from Pakistan had previously prescribed DAAs. When asked about obstacles to DAA use in their countries, the following reasons were cited: high cost, lack of availability, and lack of relevance of these DAAs to the genotypes prevalent in their countries (Table 1).

Table 1: Obstacles to DAA use.

\begin{tabular}{|c|c|}
\hline High cost & $36(54 \%)$ \\
\hline Lack of availability & $36(54 \%)$ \\
\hline $\begin{array}{c}\text { Lack of relevance of these DAAs to prevalent genotypes in our } \\
\text { country }\end{array}$ & $8(12 \%)$ \\
\hline
\end{tabular}

\section{Discussion}

The results of this study show very limited use of DAAs among hepatologists in South and South East Asia. Of the six countries represented here, half reported no access to these new medications. Apart from lack of availability, issues of cost and applicability were cited as obstacles to DAA use in the region. Newer medications, such as the polymerase inhibitor sofosbuvir with pangenotypic activity, will not have the same genotype restrictions seen with telaprevir and boceprevir. However, as our study shows, other barriers including availability and cost, may continue to impede the use of these oral antiviral agents in this region. DAAs are not in use in half of the countries studied in the region. These medicines are still relatively new and it is possible that given more time, they may reach these countries. The results of this study are limited in that all countries in the region are not represented due to their lack of participation at the conference where this study was conducted. This is the first study to look at DAA use in South and South East Asia. Based on this sample of hepatologists representing six countries from the region, there appears to be limited DAA use in South and South East Asia. Issues relating to cost, availability, and efficacy in prevalent genotypes limited DAA use in this region. In the rapidly changing landscape of hepatitis $C$ therapy, these issues need to be addressed both for the existing DAAs as well as for the array of newer agents in development.

\section{References}

1. Jacobson IM, McHutchison JG, Dusheiko G, Di Bisceglie AM, Reddy KR, Bzowej $\mathrm{NH}$, et al. Telaprevir for previously untreated chronic Hepatitis C Virus Infection. N Engl J Med. 2011; 364: 2405-2416.

2. McHutchison JG, Manns MP, Muir AJ, Terrault NA, Jacobson IM, Afdhal NH, et al. Telaprevir for previously treated chronic HCV Infection. N Engl J Med. 2010; 362: 1292-1303.

3. Poordad F, McCone J Jr, Bacon BR, Bruno S, Manns MP, Sulkowski MS et al. Boceprevir for Untreated Chronic HCV Genotype 1 Infection. N Engl J Med. 2011; 364: 1195-1206.

4. Bacon BR, Gordon SC, Lawitz E, Marcellin P, Vierling JM, Zeuzem S, et al. Boceprevir for previously treated chronic HCV genotype 1 infection. N Engl J Med. 2011; 364: 1207-1217

5. Foster GR, Hezode C, Bronowicki JP, Carosi G, Weiland O, Verlinden L, et al. Activity of telaprevir alone or in combination with peginterferon alfa-2a and ribavirin in treatment-naïve genotype 2 and 3 hepatitis $C$ patients: final results of Study C209. EASL 45th Annual Meeting; 2010 April 14-18; Vienna, Austria. 2010.

6. Waheed Y, Shafi T, Safi SZ, Qadri I. Hepatitis C virus in Pakistan: a systematic review of prevalence, genotypes, and risk factors. World J Gastroenterol. 2009; 15: 5647-5653.

7. Senevirathna D, Amuduwage $S$, Weerasingam $S$, Jayasinghe $S$ Fernandopulle N. Hepatitis $C$ virus in healthy blood donors in Sri Lanka. Asian J Transfuc Sci. 2011; 5: 23-25.

8. Pybus OG, Barnes E, Taggart R, Lemey P, Markov PV, Rasachak B, et al Genetic history of hepatitis C virus in East Asia. J Virol. 2009; 83: 1071-1082.

9. Lwin AA, Shinji T, Khin M, Win N, Obika M, Okada S, et al. Hepatitis C virus genotype distribution in Myanmar: Predominance of genotype 6 and existence of new genotype 6 subtype. Hepatol Res.2007; 37: 337-345. 